\title{
Stamford Journal of Pharmaceutical Sciences
}

\section{Orodispersible Tablets: A Short Review}

\author{
Tasbira Jesmeen, Riaz Uddin* \\ Department of Pharmacy, Stamford University Bangladesh, 51, Siddeswari Road, Dhaka-1217, Bangladesh.
}

Short Review Article

\section{INTRODUCTION}

Oral route of drug administration is the most common and preferred method of delivery (Dhirendra et al., 2009) as it is the simplest and easiest way of administering drugs (Vasconcelos et al., 2007). The rout offers ease of drug administration in a convenient manner and patients are more familiar with this rout. So, patient compliance and thus drug treatment is typically more effective with orally given medications when compared with other routes of administration, for example, parenteral (Dhirendra et al., 2009). There are strong evidences that oral administration produces equally good clinical results, has fewer complications, is less costly and causes less patient inconvenience (MacGregor and Graziani, 1997).

For any drug to exhibit its prompt pharmacologic action, its serum concentration has to reach optimum level within a short period of time (Uddin et al., 2010). Tablets and hard gelatin capsules constitute major portion of drug delivery systems that are currently available. However, many patients groups, such as the elderly, children and patients who are mentally retarded, non-cooperative, nauseated or on reduced liquid intake/diets have difficulties swallowing these dosage forms. Those who are travelling or have little access to water are similarly

\footnotetext{
*Corresponding Author

Riaz Uddin

Lecturer, Department of Pharmacy

Stamford University Bangladesh

51, Siddeswari Road

Dhaka-1217, Bangladesh

E-mail: kp_ruddin@yahoo.com

Contact No.: +8801749995653
}

affected (Mallet, 1996; Porter, 2001). To fulfill these medical needs, pharmaceutical technologists have developed a novel oral dosage form known as Orodispersible tablets (ODTs).

\section{ODTs: RAPID DISINTEGRATING ORAL DOSAGE FORM}

Orodispersible tablets are those tablets dispersing upon contact with the moist mucosal surfaces of the oral cavity and quickly release their components without mastication or water before swallowing (Ibrahim and El-Setouhy, 2010; European Pharmacopoeia, 2002; Pierre et al., 1998). ODTs disintegrate rapidly in saliva, usually in a matter of second, without the need of taking water. Thus drug dissolution and absorption as well as onset of clinical effect can be obtained significantly quicker than that of conventional dosage forms (Bradoo et al., 2001; Seager, 1998).

\section{WHY DRUGS ARE FORMULATED AS ODTs}

ODTs offer some great advantageous features over other conventional dosage forms, especially for patients of specific age groups and with disease conditions. Almost all patients encounter difficulties in taking tablets. But Difficulties with and resistance to tablet taking are common and particularly prevalent in geriatric, pediatric, and psychiatric patients (Gohel et al., 2004). Thus ODTs help a proper peroral administration in pediatric and geriatric population where swallowing is a matter of trouble (Dey and Maiti, 2010).

Dysphagia is a pathologic difficulty with swallowing. This condition is common in older indi- 
Table 1. Examples of some patented orodispersible tablets available in the market.

\begin{tabular}{|c|c|c|c|}
\hline Patented Technology & Technology Based on & $\begin{array}{c}\text { Technology developed by } \\
\text { Company }\end{array}$ & $\begin{array}{c}\text { Example } \\
\text { (Brand name) }\end{array}$ \\
\hline Zydis & Lyophilization & R.P.Scherer, Inc. & $\begin{array}{c}\text { Olanzapine } \\
\text { (Zyprexa Zydis) }\end{array}$ \\
\hline Quicksolv & & $\begin{array}{c}\text { Germany } \\
\text { Janssen Pharmaceutical Inc., }\end{array}$ & $\begin{array}{l}\text { Cisapride monohydrate } \\
\text { (Propulsid Quicksolv) }\end{array}$ \\
\hline Lyoc & & $\begin{array}{l}\text { USA } \\
\text { Farmalyoc } \\
\text { France } \\
\end{array}$ & $\begin{array}{l}\text { Phloroglucinol Hydrate } \\
\text { (Spasfon Lyoc) }\end{array}$ \\
\hline Flashtab & Direct compression & $\begin{array}{l}\text { Ethypharm } \\
\text { France }\end{array}$ & $\begin{array}{c}\text { Ibuprofen } \\
\text { (Nurofen FlashTab) }\end{array}$ \\
\hline Orasolv & & $\begin{array}{l}\text { Cima Labs, Inc. } \\
\text { USA }\end{array}$ & $\begin{array}{c}\text { Paracetamol } \\
\text { (Tempra Quicklets) }\end{array}$ \\
\hline Durasolv & & $\begin{array}{c}\text { Cima Labs, Inc. } \\
\text { USA }\end{array}$ & $\begin{array}{l}\text { Zolmitriptan } \\
\text { (Zolmig ZMT) }\end{array}$ \\
\hline Wowtab & & $\begin{array}{c}\text { Yamanouchi Pharma Tech. Inc. } \\
\text { USA }\end{array}$ & $\begin{array}{l}\text { Famotidine } \\
\text { (Gaster D) }\end{array}$ \\
\hline Ziplets & & $\begin{array}{c}\text { Eurand International } \\
\text { Italy }\end{array}$ & $\begin{array}{c}\text { Ibuprofen } \\
\text { (Cibalgina DueFast) }\end{array}$ \\
\hline Advatab & $\begin{array}{c}\text { Microcaps and diffuscap CR } \\
\text { Technology }\end{array}$ & $\begin{array}{l}\text { Eurand International } \\
\text { Italy }\end{array}$ & $\begin{array}{c}\text { Cetrizine hydrochloride } \\
\text { AdvaTab cetrizine }\end{array}$ \\
\hline Flashdose & Cotton Candy Process & $\begin{array}{c}\text { Fuisz Technology, Ltd. } \\
\text { USA }\end{array}$ & $\begin{array}{c}\text { Tramadol } \mathrm{HCl} \\
\text { (Relivia Flash dose) } \\
\end{array}$ \\
\hline Oraquick & Micromask taste masking & $\begin{array}{c}\text { KV Pharm.Co., Inc. } \\
\text { USA } \\
\end{array}$ & $\begin{array}{c}\text { Hyoscyamine Sulfate } \\
\text { ODT }\end{array}$ \\
\hline
\end{tabular}

viduals, patients with neurodegenerative diseases, such as Parkinson's disease, stroke and cancer of the head and neck and some other physical disorders including hypertension and gastroesophageal reflux disease, which can cause scarring of the esophagus and individuals with depression and/or anxiety (Llorca, 2011). Physical problems with swallowing (dysphagia) can exacerbate compliance problems and undermine treatment efficacy (Ibrahim and ElSetouhy, 2010). ODTs offers removal of the need to swallow a pill or capsule, thereby reducing the effort and physiological stress associated with tablet swallowing. Difficulty in swallowing conventional tablets and capsules has emerged as an additional factor in medication noncompliance and has led to the development of alternative drug delivery strategies such as ODTs (Navarro, 2010).

ODTs require no water (Hirani et al., 2009) and thus it is very convenient for those who are travelling in areas where there is a scarcity of water. Apart from these ODTs also offer easily measured dosing (Llorca, 2011) thus accuracy of dosage can be obtained (Ibrahim and ElSetouhy, 2010). The system gives rapid onset of action, and increase in bioavailability. The increased bioavailability of some orodispersible tablets compared to conventional tablets could be due to the dispersion in saliva and pregastric absorption. This pregastric absorption avoids first pass metabolism and can be a great advantage in drugs that undergo a great deal of hepatic metabolism (Habib et al., 2000; Chang et al., 2000).

\section{RECENT TREND OF MANUFACTURING ODTs}

The technologies used for preparation of orodispersible tablets include lyophilization, moulding, direct compression, cotton candy process, spray drying, sublimation and nanonization. These techniques are based on the principles of increasing porosity and/or addition of superdisintegrants and water soluble excipients in the tablets (Malik et al., 2011a). There are 
Table 2. Some example of recently prepared orodispersible tablets.

\begin{tabular}{|c|c|c|}
\hline Drug & Method & Reference \\
\hline Ofloxacin & $\begin{array}{l}\text { Taste masked microspheres of ofloxacin were prepared using Eu- } \\
\text { dragit and orodispersible tablets of the formulated microspheres } \\
\text { were using natural superdisintegrant. }\end{array}$ & Malik et al., 2011a \\
\hline Nimesulide & $\begin{array}{l}\text { Orodispersible tablets were prepared using locust bean gum as a } \\
\text { natural superdisintegrant. }\end{array}$ & Malik et al., 2011b \\
\hline $\begin{array}{l}\text { Cetirizine dihy- } \\
\text { drochloride }\end{array}$ & $\begin{array}{l}\text { Tablets were prepared using cetirizine along with camphor and } \\
\text { mannitol in different proportion. }\end{array}$ & Subramanian et al., 2010 \\
\hline $\begin{array}{l}\text { Pheniramine ma- } \\
\text { leate }\end{array}$ & Effervescent method & Swamy et al., 2009 \\
\hline Diazepam & $\begin{array}{l}\text { ODTs were prepared using different types of superdisintegrants at } \\
\text { different concentration using wet granulation and direct compres- } \\
\text { sion methods. }\end{array}$ & Abed et al., 2010 \\
\hline Valsartan & Tablets were prepared by freeze-drying technique. & $\begin{array}{l}\text { Ibrahim and El-Setouhy, } \\
2010\end{array}$ \\
\hline Ondansetron $\mathrm{HCl}$ & Direct compression method. & Goel et al., 2009 \\
\hline Roxithromycin & $\begin{array}{l}\text { ODTs were prepared using modified polysaccharides as rapidly } \\
\text { disintegrating excipients. }\end{array}$ & Sharma et al., 2008 \\
\hline Indomethacin & $\begin{array}{l}\text { The tablets were made by non-aqueous wet granulation technique } \\
\text { with superdisintegrant incorporated both intragranularly and ex- } \\
\text { tragranularly. }\end{array}$ & Singh et al., 2008 \\
\hline
\end{tabular}

some patented technologies for the manufacture of ODTs (Table 1). Table 2 represents examples of some recently prepared orodispersible tablets.

\section{CONCLUSION}

ODTs may disintegrate in moist condition and thus there is always a probability of deterioration of the prepared tablets. So packaging of the formulations should be considered with highest care. Moreover drugs those require sustained release are not good candidate to be formulated as ODTs. These disadvantages may limit the preparation of ODTs in some cases.

\section{REFERENCES}

Abed KK, Hussein AA, Ghareeb MM, Abdulrasool AA. (2010), Formulation and optimization of orodispersible tablets of diazepam. AAPS PharmSciTech. 11(1):356-61.

Bradoo R, Shahani S, Poojary S, Deewan B, Sudarshan S. (2001), Fast dissolving drug delivery system. J Am Med Assoc India. 4(10): 27-31.
Chang RK, Guo X, Burnside B, Couch R. (2000), Fastdissolving tablets. Pharm Technol. 24(6):52-8.

Dey P, Maiti S. (2010), Orodispersible tablets: A new trend in drug delivery. Natural Science. 1(1): 2-5.

Dhirendra K, Lewis S, Udupa N, Atin K. (2009), Solid Dispersions: A Review. Pak J Pharm Sci. 22 (2): 234246.

European Pharmacopoeia; 4th ed., Suppl. 4.1. Council of Europe, Strasbourge, France; 2002. p. 2435.

Goel H, Vora N, Tiwary AK, Rana V. (2009), Formulation of orodispersible tablets of ondansetron $\mathrm{HCl}$ : investigations using glycine-chitosan mixture as superdisintegrant. Yakugaku Zasshi. 129(5):513-21.

Gohel M, Patel M, Amin A, Agrawal R, Dave R, Bariya N. (2004), Formulation design and optimization of mouth dissolve tablets of nimesulide using vacuum drying technique. AAPS PharmSci- Tech. 5(3):e36.

Habib W, Khankari R, Hontz J. (2000), Fast-dissolving drug delivery systems, critical review in therapeutics. Drug Carrier Systems. 17(1):61-72.

Hirani JJ, Rathod DA, Vadalia KR. (2009), Orally disintegrating tablets: a review. Trop J Pharm Res. 8(2): 161-172. 
Ibrahim HK, El-Setouhy DA. (2010), Valsartan orodispersible tablets: formulation, in vitro/in vivo characterization. AAPS PharmSciTech. 11(1):189-96.

Llorca P-M. (2011), Discussion of prevalence and management of discomfort when swallowing pills: orodispersible tablets expand treatment options in patients with depression. Therapeutic Delivery. 2(5): 611-622.

MacGregor RR, Graziani AL. (1997), Oral Administration of Antibiotics: A Rational Alternative to the Parenteral Route. Clinical Infectious Diseases. 24:457-67.

Malik K, Arora G, Singh I. (2011a), Taste Masked Microspheres of Ofloxacin: Formulation and Evaluation of Orodispersible Tablets. Sci Pharm. 79(3):653-672.

Malik K, Arora G, Singh I. (2011b), Locust bean gum as superdisintegrant--formulation and evaluation of nimesulide orodispersible tablets. Polim Med. 41(1):17-28.

Mallet L. (1996), Caring for the Elderly Patients. J Am Pharm Assoc. 36(11): 628-635.

Navarro V. (2010), Improving medication compliance in patients with depression: Use of orodispersible tablets. Advances in Therapy. 27(11): 785-795.

Pierre H, Matthias S, Rosa M. (1998), Fast disintegrating oral dosage form.US Patent 6,083,531.

Porter SC. (2001), Novel drug delivery: Review of recent trends with oral solid dosage forms. Am Pharm Rev. 85: 28-35.

Seager H. (1998), Drug-delivery products and Zydis fast dissolving dosage form. J Pharm Pharmacol. 50(4): 375-382.

Sharma V, Philip AK, Pathak K. (2008), Modified polysaccharides as fast disintegrating excipients for orodispersible tablets of roxithromycin AAPS PharmSciTech. 9(1):87-94.

Singh J, Philip AK, Pathak K. (2008), Optimization studies on design and evaluation of orodispersible pediatric formulation of indomethacin. AAPS PharmSciTech. 9(1):60-6.

Subramanian S, Sankar V, Manakadan AA, Ismail S, Andhuvan G. (2010), Formulation and evaluation of Cetirizine dihydrochloride orodispersible tablet. Pak J Pharm Sci. 23(2):232-5.

Swamy PV, Divate SP, Shirsand SB, Rajendra P. (2009), Preparation and evaluation of orodispersible tablets of pheniramine maleate by effervescent method. Indian J Pharm Sci. 71(2):151-4.

Uddin R, Saffoon N, Huda NH, Jhanker YM. (2010), Effect of Water Soluble Polymers on Dissolution Enhancement of Ibuprofen Solid Dispersion Prepared by Fusion Method. Stamford Journal of Pharmaceutical Sciences. 3(1): 63-67.
Vasconcelos T, Sarmento B, Costa P. (2007), Solid dispersions as strategy to improve oral bioavailability of poor water soluble drugs. Drug Discov Today. 12(23/24): 1068-1075. 